\title{
Kaempferol promotes memory retention and density of hippocampal CA1 neurons in intra-cerebroventricular STZ-induced experimental AD model in Wistar rats
}

\author{
Niloufar Darbandi ${ }^{*}$, \\ Matin Ramezani ${ }^{1}$, \\ Fariba Khodagholi', \\ Mitra Noori ${ }^{1}$ \\ ${ }^{1}$ Department of Biology, \\ Faculty of Science, \\ University of Arak, \\ Arak 38156-8-8349, Iran \\ ${ }^{2}$ NeuroBiology Research Center, \\ Shahid Beheshti University of \\ Medical Sciences, Tehran, Iran
}

Background. Alzheimer's disease (AD) is a progressive degenerative disease which causes memory disorders, decreases cognitive functions and abilities, and results in behavioural changes. Some studies have indicated that the flavonoids are able to cross the blood-brain barrier and have a positive effect on the reduction of neuronal damage disorders in the brain such as Alzheimer's disease.

Materials and Methods. ICV administration of streptozotocin ( $3 \mathrm{mg} / \mathrm{kg}$ ) was done on the first and the third day of the surgery and the animals' memory was evaluated through passive avoidance tasks. Animals were divided into five groups: Salin-Salin, STZ-Salin, and STZ- different kaempferol doses $(5,7 / 5,10 \mathrm{mg} / \mathrm{kg})$. All animals received different doses of kaempferol or saline for 3 weeks starting one day before the surgery. Later, they were put into a learning test. After the memory test, the animals were killed and their brains were fixed with Paraformaldehyde 4\%, and tissue processing was done. Finally, density of intact neurons in the CA1 area of the hippocampus in the brains of all groups was investigated.

Results. The ICV injections of STZ significantly reduced memory retention and intact pyramidal cells compared to the control group. The kaempferol improved the effects of STZ.

Conclusion. Our findings show that kaempferol can optimize cognitive deficits caused by injections of STZ and also has some useful impacts on hippocampal CA1 pyramidal neurons.

Keywords: Kaempferol, STZ, memory, hippocampal CA1

\section{INTRODUCTION}

Alzheimer's disease (AD), the most prevalent form of dementia, is a progressive degenerative disease which causes memory disorders, decreases cogni-

\footnotetext{
Corresponding author. E-mail: N-Darbandi@araku.ac.ir
}

tive functions and cognitive abilities, and leads to behavioural changes (Newman et al., 2007). Both environmental and genetic factors contribute to the pathogenesis of AD. The formation of extracellular amyloid plaques, and accumulation of intracellular neurofibrillary tangles are the neuropathological symptoms of AD (Vauzour, 2014). 
The hippocampus is a critical brain area for learning and memory, and evidence has shown altered neurogenesis in the adult hippocampus at early stages of Alzheimer's disease ( $\mathrm{Mu}$, Gage, 2011). The hippocampal formation includes the dentate gyrus (DG), hippocampus proper (fields CA3, CA2, CA1), and the subiculum (Agster, Burwell 2013). The hippocampus and, in particular, the output layer of subfield CA1 has the highest concentration of N-Methyl$\mathrm{D}$-aspartate (NMDA) receptors in the brain. These receptors are a type of glutamate receptor whose activity underlies long-term potentiation (Wible, 2013).

ICV administration of STZ in rats causes long-term and progressive deficits in learning and cognitive performance that are similar to the sporadic kind of AD (Baluchnejadmojarad, 2009). It appears that this drug can lead to insulin resistance in brain cells, increases glucose in the brain, and reduces the energy available to the cells (Roghani, Baluchnejadmojarad, 2006). By increasing glucose in the brain, streptozotocine increases processed amyloid precursor protein to beta-amyloid and intensifies the inflammatory process in rats' brain. This combination reduces insulin expression in the hippocampus and cerebral cortex (Chu, Qian, 2005), causes a reduction in protein kinase $\mathrm{C}$ activity and oxidative stress, and increases the production of ROS and RNS and the ratio of $\mathrm{Bax} / \mathrm{Bcl} 2$ in the hippocampus (Kundurovic et al., 2009). An increase in the amount of caspase-3 in the cerebral cortex and the hippocampus leads to the apoptosis of the neurons in these areas (Ejaz Ahmed et al., 2013). Also, the research suggests that by increasing the production of free radicals and lipid oxidation in BCL2 nerve cells betaamyloid leads to the cell death (Heo et al., 2004).

Over the last decade, growing research has focused on the potential of dietary flavonoids in reducing the risk of $\mathrm{AD}$ and other dementing disorders (Vauzour, 2014). Research shows the connection between normal ageing and neurodegenerative diseases such as $\mathrm{AD}$ with oxidative stress and inflammatory factors. Flavonoids have neuroprotective and neurogenetic effects. These compounds have the ca- pacity to cross the blood-brain barrier, and can scavenge free radicals with several mechanisms in order to prevent the occurrence of oxidative stress. Flavonoids lead to the absorption of free radicals and inhibit the reactive oxygen in free radicals (Choi et al., 2003). Flavonoids can reduce the inflammatory cytokines and the production of beta-amyloid and increase the sensitivity of cells to insulin (Rendeiro et al., 2012). Flavonoids have the potential to enhance memory and learning by activating the MAPK and PI3 kinase pathways that are critical in controlling the morphological mechanisms behind memory storage in the brain (Krishnaveni, 2012). Indeed, flavonoids are able to influence neuroprotective actions, neuronal survival and differentiation, long-term potentiation (LTP) and memory (Krishnaveni, 2012).

In view of the facts that flavonoids (a) reduce oxidative stress and inflammatory cytokine levels, (b) increase the sensitivity of cells to insulin, (c) have neuroprotective effects, (d) increase neuronal survival and differentiation, and (e) affect long-term potentiation and memory, the present study investigates the effect of flavonoid kaempferol on memory retention and the hippocampal CA1 neurons in Alzheimer's male rats.

\section{MATERIALS AND METHODS}

\section{Animals}

Male Wistar rats (Pasteur Institute; Tehran, Iran) weighing 220-250 $\mathrm{g}$ at the time of surgery were used. The animals were kept in an animal house under a 12-h light/12-h dark cycle and in controlled $\left(22 \pm 2^{\circ} \mathrm{C}\right)$ temperature. They had free access to food and water. All animals were allowed to adapt to the laboratory conditions for at least 1 week before the surgery and were handled for $5 \mathrm{~min} /$ day during this adaptation period. Each animal was used once only. Eight animals were used in each experimental group and all procedures for the treatment of the animals were approved by the Research and Ethics Committee of the Biology School, the University of Arak, and were done in accordance with the National Institutes of Health Guide for Care and Use of Laboratory Animals. 


\section{Surgical and infusion procedures}

All surgical procedures were conducted under ketamine-xylazine $(50 \mathrm{mg} / \mathrm{kg}$ ketamine $-5 \mathrm{mg} / \mathrm{kg}$ xylazine) anesthesia (Roghani et al., 2006). Stainless steel, 22-gauge guide cannulas were implanted (bilaterally) $1 \mathrm{~mm}$ above the intended site of injection according to the Paxinos and Watson atlas (Paxinos, Watson, 1998). Stereotaxic coordinates for lateral ventricle were incisor bar $(-3.3 \mathrm{~mm}), 0.8 \mathrm{~mm}$ posterior to the bregma, $\pm 1.4 \mathrm{~mm}$ lateral to the sagittal suture and $3.4 \mathrm{~mm}$ from the top of the skull. Cannulas were secured to anchor jewellers' screws with dental acrylic. For drug infusion, the animals were gently restrained by hand and injected by 27 -gauge injection needles $(1 \mathrm{~mm}$ below the tip of the guide cannulas). Each injection unit was injected by polyethylene tubing to $25 \mu \mathrm{l}$ Hamilton syringe. The left and right ventricles were infused with a $10 \mu \mathrm{l}$ solution on each side $(20 \mu \mathrm{l} / \mathrm{rat})$ for 2 to 3 minutes. The injection needles were left in place for additional $60 \mathrm{~s}$ to allow diffusion and then the styles were reinserted into the guide cannulas.

\section{Passive avoidance apparatus}

The learning box consisted of two compartments, one light (white compartment, $20 \times 20$ $\times 30 \mathrm{~cm}$ ) and the other dark (black compartment, $20 \times 20 \times 30 \mathrm{~cm}$ ). A guillotine door opening $(7 \times 9 \mathrm{~cm})$ was made on the floor in the centre of the partition between the two compartments. Stainless steel graids $(2 / 5 \mathrm{~mm}$ in diameter) were placed at $1 \mathrm{~cm}$ intervals (distance between the centres of grades) on the floor of the dark compartment to produce a foot shock. Intermittent electric shocks $(1 \mathrm{~Hz}, 3 \mathrm{~s}, 1 / 5 \mathrm{~mA})$ were delivered to the grid floor of the dark compartment by an insulated stimulator.

\section{Training}

Training was based on our previous studies (Ejaz Ahmed et al., 2013). All animals were allowed to habituate in the experimental room for at least 30 min prior to the experiments. Then, each animal was gently placed in the brightly lit compartment of the apparatus; after five seconds, the guillotine door was opened and the animal was allowed to enter the dark compartment. The latency with which the animal crossed into the compartment was recorded. The animals that waited for more than $100 \mathrm{~s}$ to cross to the dark compartment were eliminated from the experiments. Once the animal crossed, on all four paws, to the next compartment, the guillotine door was closed and the rat was taken into its cage (habituation trail). The acquisition trail was carried out $30 \mathrm{~min}$ after the habituation trail. The animal was placed in the light compartment and $5 \mathrm{~s}$ later the guillotine door was opened and as soon as the animal crossed to the dark (shock) compartment the door was closed and a foot shock ( $1 \mathrm{~Hz}, 1 / 5 \mathrm{~mA}$ and $3 \mathrm{~s})$ was immediately delivered to the grid floor of the dark room. After $20 \mathrm{~s}$, the rat was removed from the apparatus and placed temporarily into its cage. After 2 minutes, the procedure was repeated. The rat received a foot shock each time it re-entered the dark part and placed all four paws in the compartment. The training was terminated once the rat remained in the light compartment for 120 consecutive seconds. The numbers of trails (entries into the dark chamber) were recorded. All the animals were taught with a maximum of 3 trails.

\section{Retention test}

Twenty-four hours after the training, a retention test was performed to determine longterm memory. Each animal was placed in the light compartment for $20 \mathrm{~s}$, the door was opened and the step-through latency was measured for entering into the dark compartment. The test session ended when the animal entered the dark compartment or remained in the light compartment for $300 \mathrm{~s}$ (criterion for retention). During these sessions, no electric shock was applied (Roghani et al., 2007).

\section{Drugs}

The drugs used in the study were streptozotocin (Sigma-Aldrich, USA) and kaempferol (SigmaAldrich, USA). The drugs were dissolved in sterile $0.9 \%$ saline, just before the experiment. Streptozotocin was administered into the lateral ventricle, and kaempferol or saline were injected intraperitoneally (i.p.). 


\section{Experimental procedure}

Eight animals were chosen in each experimental group. The therapeutic period was 21 days for all the rats. They were treated on the first and the third day by STZ ( $3 \mathrm{mg} / \mathrm{kg}$; i.c.v.; bilateral with $10 \mu \mathrm{l}$ volume in either side), or saline as a placebo (i.c.v.; bilateral with $10 \mu \mathrm{l}$ volume in either side). All the STZ or saline recipient animals were infused for 21 days with different doses of flavonoids (5, 7.5, $10 \mathrm{mg} / \mathrm{kg}$ i.p.) or saline ( $\mathrm{ml} / \mathrm{kg}$ i.p.) starting one day before the surgery. On day 22 , without any treatment, the rats were trained in step-through apparatus. Twenty-four hours later, a retention test was performed to determine the rate of long-term memory. All experiments were performed in the morning between 9:00 and 12:00.

All rats were anesthetized with $3.5 \%$ chloral hydrate $(35 \mathrm{mg} / 100 \mathrm{~g}$ intraperitoneal) and perfused through the left ventricle with phosphate buffer (PBS, 0.1 M, pH 7.4), followed by $4 \%$ paraformaldehyde in pre-cooled physiological saline. The brains were removed and immersed in the same solution (24 or 48 hours) and were then processed and embedded in paraffin. Coronal sections, $10 \mu \mathrm{m}$ in thickness, were taken from the dorsal hippocampus and stained with hematoxylin and eosin. Pyramidal cells with a distinct nucleus and nucleolus were regarded as intact neurons. The surviving cells were defined as round-shaped, cytoplasmic membrane-intact cells, without any nuclear condensation or distorted aspect. The number of intact neurons in $1 \mathrm{~mm}$ length of the middle portion of the right hippocampal CA1 subfield was counted using a microscope at $\times 400$ magnification by an inspector blinded to the intervention (Liu et al., 2010).

\section{The effects of the injection of streptozotocine or different doses of kaempferol on memory retrieval}

In this experiment, five groups of animals were treated on the first and the third day of the surgery by STZ (3 mg/kg; i.c.v.; bilateral with $10 \mu$ l volume in either side) or saline as a placebo (i.c.v.; bilateral with $10 \mu \mathrm{l}$ volume in either side). All the animals were infused with saline ( $\mathrm{ml} / \mathrm{kg}$ i.p.) or different doses of kaempferol $(5,7.5,10 \mathrm{mg} / \mathrm{kg}$ i.p.) for 21 days. On day 22 , without any treatment, the rats were trained in step-through apparatus. Twentyfour hours later, a retention test was performed to determine the rate of the long-term memory (Fig. 1).

\section{Verification of the placements of cannulas}

At the end of the experiment, to assess the validity and accuracy of the coordinates of the surgical site and the injection, 1 micro litre

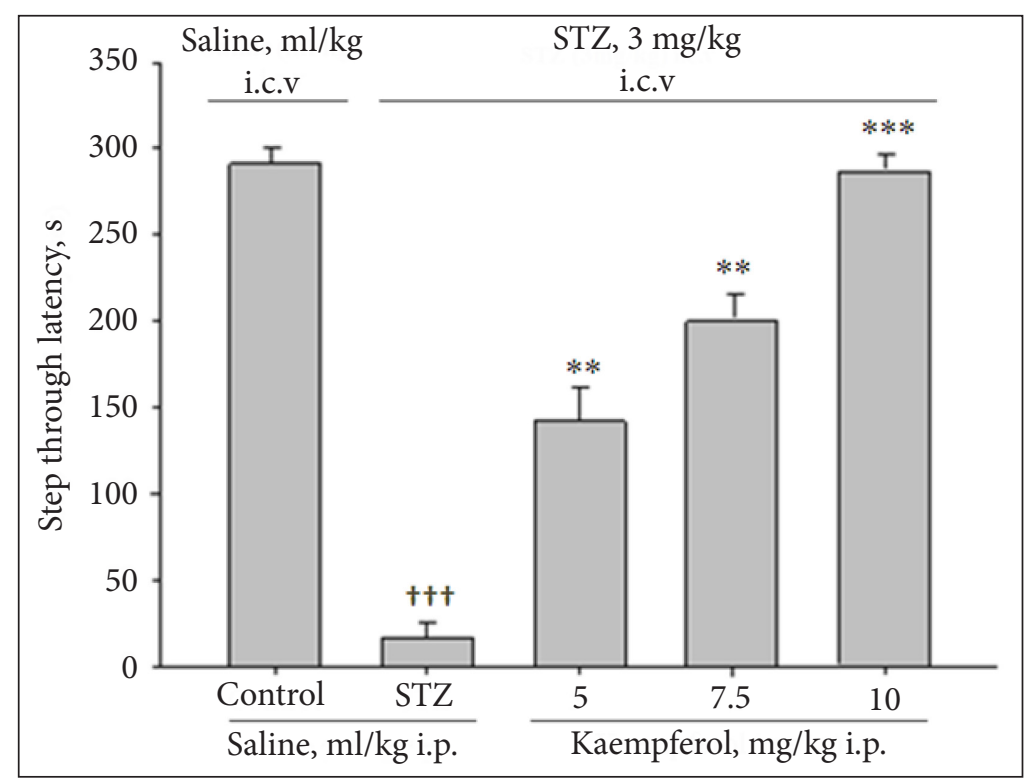

Fig. 1. Streptozotocin-induced amnesia in the STZ group compared to the control group. Intraperitoneal injections of kaempferol significantly improved memory retention and increased the delay in entering the dark room. Results are expressed as (Mean \pm SEM) for all the eight animals. ${ }^{++} P<0 / 001$ compared with control group. ${ }^{* *} P<0 / 01,{ }^{* * *} P<0 / 001$ is compared to the STZ group 
of $1 \%$ aqueous solution of methylene blue was bilaterally injected. Animal brain was removed from the skull and was fixed in 10\% formalin solution for 10 days. Sections were examined to determine the location of the cannulas aimed for the lateral ventricle. The cannula placements were verified using the atlas of Paxinos and Watson (Paxinos, Watson 1988). Data from the animals with the injection sites located outside the lateral ventricle (less than 5\%) were not used in the analysis.

\section{Statistics}

The avoidance test data are expressed as means \pm S.E.M. The statistical analyses were performed using one-way analysis of variance (ANOVA). The post-hoc comparison of means was carried out with the Tukey test for multiple comparisons, when appropriate. The average of intact cells in hippocampal CA1 pyramidal neurons data was analyzed by the prism software and analysis of variance with repeated measures was done at the same time. We used one-way analysis of variance (ANOVA) a t-test for comparison of the groups. The level of statistical significance was set at $p<0.05$. Calculations were performed using the SPSS statistical package. Charts were drawn by the Sigma plot software.

\section{RESULTS}

\section{The effects of ICV injection of streptozotocin and the different doses of kaempferol on memory retention}

As Fig. 1 shows, intraventricular injections of streptozotocin $(3 \mathrm{mg} / \mathrm{kg})$ on the first and the third day of the surgery decreased the memory retention compared to the control group. This means that STZ creates a significant reduction of delay in entering the dark room and reduces memory in 24 hours. Oneway ANOVA showed that the administration of different doses of kaempferol $(5,7.5$ and $10 \mathrm{mg} / \mathrm{kg}$ i.p.), 21 days before the training and ICV injections of STZ $(3 \mathrm{mg} / \mathrm{kg})$ on the first and the third days of surgery improved memory with different ratios compared to the STZ group. The Tukey complementary test showed that treatment with different doses of kaempferol significantly increased the delay in entering a dark room, suggesting an improvement of the memory. The maximum effect was observed with $10 \mathrm{mg} / \mathrm{kg}$ of kaempferol ([F(4, 32) $=29 / 916, P<0 / 001])$.

As shown in Fig. 2, one-way ANOVA revealed that the time spent in the dark room was significantly different between the control group, STZ group and the groups treated with

Fig. 2. The time spent in the dark room in rats with Alzheimer's disease increased compared to the control group. Intraperitoneal injections of kaempferol in rats with $\mathrm{Alz}$ heimer's disease dose-dependently decreased this time and improved memory. Results are expressed as (Mean \pm SEM) for all the eight animals. ** $P<0 / 01$, *** $P<0 / 001$ is compared to the control group

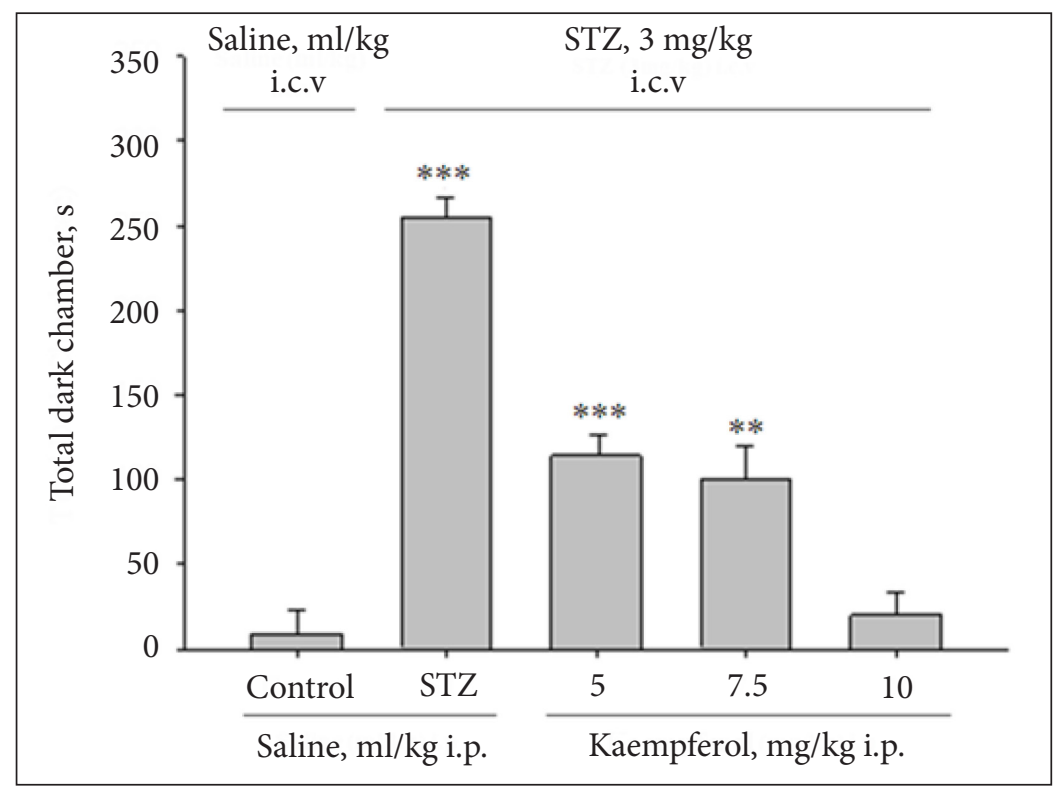


different doses of kaempferol (5, 7.5 and $10 \mathrm{mg} /$ $\mathrm{kg}$ i.p.). An increase in the time of TDC means a decrease in memory and therefore the animals spent more time in the dark room $([\mathrm{F}(4$, $34)=65 / 18, P<0 / 001])$.

As Fig. 3 shows, the administration of kaempferol (10 mg/kg i.p.) alone, 21 days before the training did not have any significant effect on memory retention compared to the control group $([\mathrm{F}(3,28)=105 / 32, P<0 / 001])$. As a result, treatment with kaempferol $(10 \mathrm{mg} / \mathrm{kg}$ i.p.) alone had no significant effect on memory but the administration of kaempferol $(10 \mathrm{mg} /$ $\mathrm{kg}$ i.p.) 21 days before training and ICV injections of STZ $(3 \mathrm{mg} / \mathrm{kg})$ on the first and the third days of surgery significantly improved memory compared to the STZ group.

\section{Histology and comparison of the average number of intact cells}

Histological examination was carried out on $\mathrm{H} \&$ E-stained slices of rats brain 21 days after the ICV administrations. The slices showed that saline failed to produce any significant neuronal damage in the control animals, but the STZ (3 $\mathrm{mg} / \mathrm{kg}$ ) produced a significant neuronal death in the hippocampal CA1 neurons. Kaempferol treatment $(5,7.5,10 \mathrm{mg} / \mathrm{kg}$ i.p.), could protect neurons from STZ-induced damage (Fig. 4).

Regarding the population of neurons counted in the hippocampal CA1 area, we observed a significant decrease $(P<0.001)$ in the number of neurons in the CA1 area of STZ group, comparing with control group (Fig. 5). Also, examination of the present data showed that kaempferol (5, 7.5 and 10) significantly increased the number of intact cells compared to the STZ group $([\mathrm{F}(4,60)=117, P<0.001])$ (Fig. 5).

\section{DISCUSSION}

Based on the results obtained from this study, the ICV injection of STZ $(3 \mathrm{mg} / \mathrm{kg})$ is the main cause to destroy memory retention. Histological studies indicated that the number of pyramidal neurons in hippocampal CA1 was significantly decreased in the STZ group compared to that in the control group $(P<0.001$, Fig. 4). Also, the hippocampal CA1 pyramidal neurons in

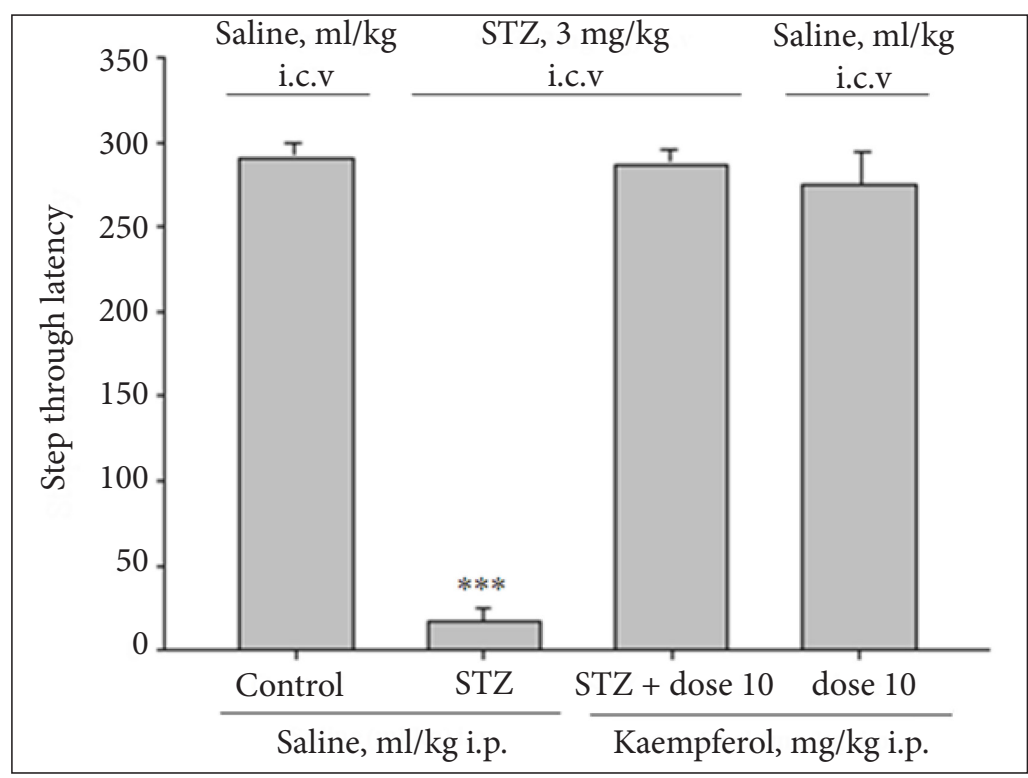

Fig. 3. The administration of kaempferol ( $10 \mathrm{mg} / \mathrm{kg}$ i.p.) alone 21 days before the training did not have any significant effect on memory retention compared to the control group. Results were expressed as (Mean \pm SEM) for all the eight animals. ${ }^{* *} P<0 / 001$ is compared to the control group 


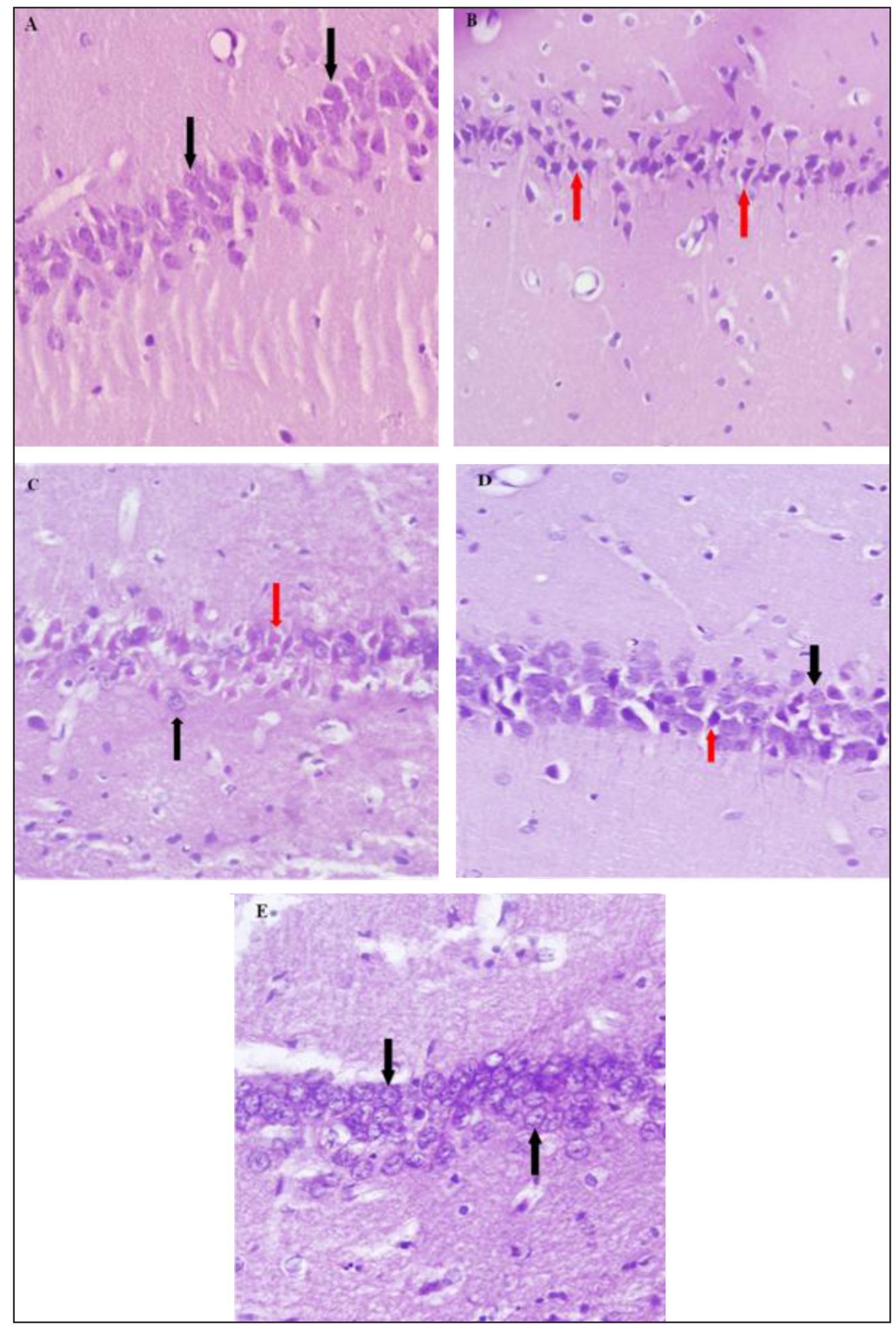

Fig. 4. Photomicrographs of typical coronal sections through the CA1 pyramidal neurons of the hippocampus showing Hematoxilin \& Eosin in A: Control, B: Streptozotocin group, C: STZ+ dose 5 of kaempferol, D: STZ + dose 7.5 of kaempferol and F: STZ + dose 10 of kaempferol. Black arrows show intact cells and red arrows show degenerating pyramidal cells $\times 400$ 


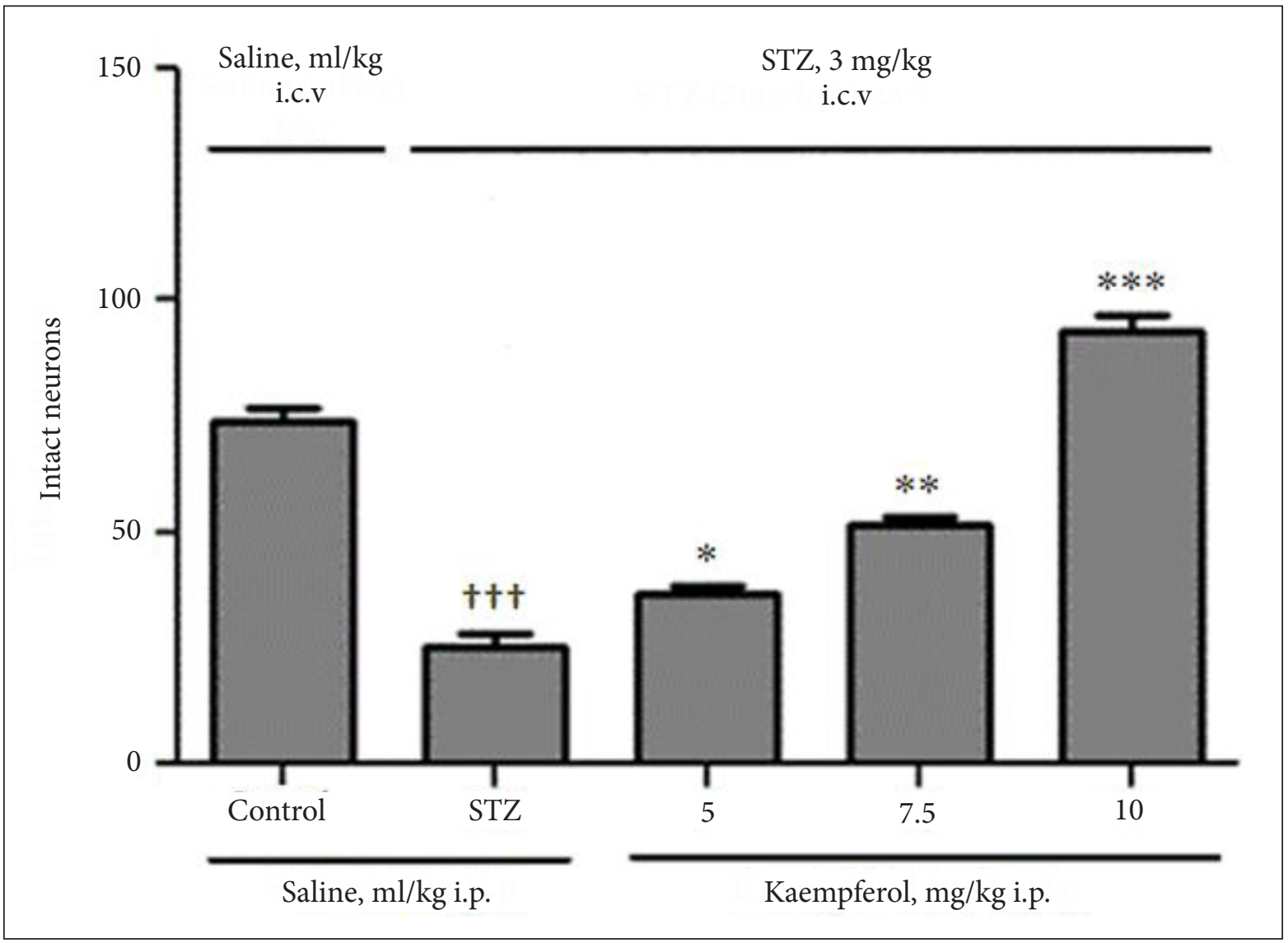

Fig. 5. Neuron density in the CA1 area of the hippocampus in the brains of all groups. Results are expressed as (Mean \pm SEM) for all the eight animals. $\dagger \dagger \dagger P<0.001$ is compared to the control group. ${ }^{\star} P<0.05$, ${ }^{* *} P<0.01,{ }^{* *} P<0.001$ is compared to the STZ group

the brains of the control and STZ groups were indicative of significant structural differences between these two groups. The hippocampal CA1 cells in the control group (Fig. 3A), had a natural structure and were regulated and uniformed; they were very clear and had a single nucleus with the neurons located regularly in the CA1 pyramidal layer. However, in the STZ group (Fig. 3B), a severe reduction of intact cells was observed and there was an increase in the number of dead cells; the pyramidal layer did not have a unified and regulated structure. In these neurons a remarkable change in the morphology, such as shrinkage and atrophy, was found in all cells, and the cells had become smaller with free spaces around them. Because of the loss of intracellular contents, the dead cells had accepted extra colour.
Previous studies confirm our findings (Rai et al., 2013). ICV administration of STZ in rats causes long-term and progressive deficits in learning and cognitive performance that is similar to the sporadic kind of AD (Baluchnejadmojarad, 2009). STZ increases glucose in rats' brain, leads to increase processed amyloid precursor protein to beta-amyloid and intensifies the inflammatory process. This combination reduces insulin expression in the hippocampus and cerebral cortex (Chu, Qian, 2005) and increases oxidative stress, the production of ROS and RNS and the ratio of $\mathrm{Bax} / \mathrm{Bcl} 2$ in the hippocampus (Kundurovicet et al., 2009). By increasing the amount of caspase- 3 in the cerebral cortex and hippocampus, the neurons undergo apoptosis (Ejaz Ahmedet et al., 2013). Beta-amyloid and 
STZ, by increasing the production of free radicals and cytotoxicity due to DNA alkylation, lead to cell death (Heoet et al., 2004).

In this study, combined treatment of rats with STZ $(3 \mathrm{mg} / \mathrm{kg})$ and kaempferol $(5,7.5$, $10 \mathrm{mg} / \mathrm{kg}$ i.p.) significantly improved memory retention. Also, histological investigation demonstrated that in the STZ+ kaempferol group (5, 7.5 and $10 \mathrm{mg} / \mathrm{kg} /$ day, i.p.), the number of intact cells gradually increased and the number of dead cells decreased (Fig. 3C, D, E). An increase in the doses of kaempferol neutralized STZ-induced toxicity and allowed the proliferation to hippocampus. Morphological variations were highly significant in each group. In the STZ+dose 10 of kaempferol, the effect of STZ was completely neutralized and consecutive cell divisions were observed.

Research has indicated that phytochemicalrich foods, particularly those rich in flavonoids, may exert especially powerful effects on cognitive functions (Vauzour, 2014). Flavonoids have a number of effects on the brain, including a potential of protection of neurons against injuries induced by neurotoxins and promotion of learning and memory (Spencer, 2009). Supplementation of diet with antioxidant-rich foods significantly reduces the age-related memory impairment and increases protective responses to oxidative stress and mitochondrial dysfunction (Goyarzu et al., 2004).

Researches have shown that kaempferol has antioxidant activity (Kampkotter et al., 2007; Verma et al., 2009). Kaempferol scavenges hydroxyl radical and peroxynitrite that damage DNA, proteins and lipids (Wang et al., 2006). Kaempferol inhibits the activity of enzymes that generate ROS (Wanget al., 2006; Ozyurek et al., 2009). Kaempferol increases the expression or activity of antioxidant enzymes (Doronicheva et al., 2007; Hong et al., 2009). Furthermore, kaempferol prevents lipid peroxidation (Ozgova et al., 2003; Vareed et al., 2007; Hou et al., 2004).

It is accepted that the process of learning involves reversible changes in synaptic transmission and synaptic plasticity within hippocampal neuronal circuitry which allow memory to be retained (Rendeiro et al., 2012). Mechanisms of flavonoids in the brain are not clear, however, there is evidence to suggest that flavonoids can cross the blood-brain barrier (BBB) and have been shown to affect different aspects of synaptic plasticity, regulation of receptors activation, modulation of signalling pathways, activation of transcription factors, and regulation of gene and protein expression and promotion of LTP (Rendeiro et al., 2012). Green tea flavanols increase levels of hippocampal CREB phosphorylation, additionally can increase levels of $\mathrm{BDNF}$ and Bcl-2. BDNF is involved in translation of neuronal signals into structural changes in the synapse (Rendeiro et al., 2012). By activation of a number of protein kinase and lipid kinase signalling cascades such as the PI3 kinase (PI3K)/Akt, tyrosine kinase, protein kinase $\mathrm{C}$ (PKC) and MAPK signalling pathways, flavonoids can lead to the inhibition of apoptosis triggered by neurotoxic species, and to the promotion of neuronal survival and differentiation (Spencer, 2009). Also, some research indicates that flavonoids induce peripheral and cerebral vascular blood flow and lead to the induction of angiogenesis and new nerve cell growth in the hippocampus (Spencer, 2009). Activated microglia and/or astrocytes release cytokines production (IL-1b, TNF-a), inducible nitric oxide synthase (iNOS) and nitric oxide (NO•), and increase NADPH oxidase activation that leads to glial-induced neuronal death (Spencer, 2009). It has been found that flavonoids are highly effective in inhibition of NO•, IL-1b and TNF-a production in activated microglia cells (Spencer, 2009).

Our results showed neuronal loss in the hippocampus of the STZ group, compared with the control group. This was mainly expressed by a significant reduction in neuronal density in the CA1 hippocampal area. Many central disorders are associated with hippocampal neuronal loss (Azad et al., 2011). In general, the number of neurons, the dendritic branches, and synaptic activity determine the functional capacity in the brain (Padurariu et al., 2012). Lack of neurons in the hippocampus of $\mathrm{AD}$ can explain memory disturbances in $\mathrm{AD}$. Our findings show 
that kaempferol can optimize cognitive deficits caused by injections of STZ, increase dosedependently the number of intact cells and decrease the number of dead cells in CA1 hippocampus area.

\section{CONCLUSIONS}

The ICV injection of STZ (3 mg/kg) induced amnesia and decreased the number of pyramidal intact neurons in hippocampal CA1 area in the STZ group compared to that in the control group. In this study, combined treatment of rats with STZ and kaempferol significantly improved memory retention, and the number of intact cells in hippocampal CA1 area gradually increased and the number of dead cells decreased.

Received 26 June 2016 Accepted 20 August 2016

\section{References}

1. Agster KL, Burwell RD. Hippocampal and subicular efferents and afferents of the perirhinal, postrhinal, and entorhinal cortices of the rat. Behavioural brain research. 2013; 1 : 50-64.

2. Azad N, Rasoolijazi H, Joghataie MT, Soleimani S. Neuroprotective Effects of Carnosic Acid in an Experimental Model of Alzheimer's Disease in Rats. Cell Journal. 2011; 13(1): 39-44.

3. Baluchnejadmojarad T. The Effect of Genistein on Intracerebroventricular StreptozotocinInduced Cognitive Deficits in Male Rat. Basic and Clinical Neuroscience. 2009; 1(1): 17-21.

4. Choi YJ, Kang JS, Park JH, Lee YJ, Choi JS, Kang YH. Polyphenolic flavonoids differ in their antiapoptotic efficacy in hydrogen peroxide-treated human vascular endothelial cells. The Journal of Nutrition. 2003; 133(4): 985-91.

5. Doronicheva N, Yasui H, Sakurai H. Chemical structure dependent differential effects of flavonoids on the catalase activity as evaluated by a chemiluminescent method Biol. Pharm. Bull. 2007; 30: 213-7.

6. Ejaz Ahmed M, Khan MM, Javed H, Vaibhav K, Khan A, Tabassum R, Ashafaq M, Islam F, Safhi MM, Islam F. Amelioration of cognitive impairment and neurodegeneration by catechin hydrate in rat model of streptozotocin-induced experimental dementia of Alzheimer's type. Neurochemistry International. 2013; 62(4): 492-501.

7. Goyarzu P, Malin DH, Lau FC, Taglialatela G, Moon WD, Jennings R, Moy E, Moy D, Lippold S, Shukitt-Hale B, Joseph JA. Blueberry supplemented diet: effects on object recognition memoryand nuclear factor-kappa B levels in aged rats. Nutritional Neuroscience. 2004; 7(2): 75-83.

8. Heo HJ, Kim DO, Shin SC, Kim MJ, Kim BG, Shin DH. Effect of antioxidant Flavanone, Naringenin, from Citrus Junoson Neuroprotection. Journal of Agricultural and Food Chemistry. 2004; 52(6): 1520-5.

9. Hong JT, Yen JH, Wang L, Lo YH, Chen ZT, Wu MJ. Regulation of heme oxygenase-1 expression and MAPK pathways in response to kaempferol and rhamnocitrin in PC12 cells. Toxicol. Appl. Pharmacol. 2009; 237: 59-68.

10. Hou L, Zhou B, Yang L, Liu ZL. Inhibition of free radical initiated peroxidation of human erythrocyte ghosts by flavonols and their glycosides. Org. Biomol. Chem. 2004; 2: 1419-23.

11. Kampkotter A, Gombitang NC, Zurawski RF, Timpel C, Chovolou Y, Watjen W, Kahl R. Effects of the flavonoids kaempferol and fisetin on thermotolerance, oxidative stress and FoxO transcription factor DAF-16 in the model organism Caenorhabditis elegans. Arch. Toxicol. 2007; 81: 849-58.

12. Krishnaveni M. Flavonoid In Enhancing Memory Function. Journal of Pharmacy Research. 2012; 5(7): 3870-4.

13. Kundurovic Z, Hasanagic S, Bilalovic N, Gavrankapetanovic F, Alicelebic S. Pro-apoptotic protein Bax and anti-apoptotic protein 
Bcl-2 expression in streptozotocin model of Alzheimer's disease. Health Med Academic Journal. E. OR (S). 2009; 3(4): 520.

14. Liu J, Wang A, Li L, Huang Y, Xue P, Hao A. Oxidative stress mediates hippocampal neuron death in rats after lithium-pilocarpine-induced status epilepticus. Seizure. 2010; 19(3): 165-72.

15. Mehla J, Pahuja M, Gupta YK. Streptozotocininduced sporadic Alzheimer's disease: selection of appropriate dose. Journal of Alzheimer's disease. 2013; 33(1): 17-21.

16. Nabavi SF, Nabavi SM, Ebrahimzadeh MA, Asgarirad $\mathrm{H}$. The antioxidant activity of wild medlar (Mespilus germanica L.) fruit, stem bark and leaf. African Journal of Biotechnology. 2011; 10(2): 283-9.

17. Newman M, Musgrave FI, Lardelli M. Alzheimer disease: Amyloidogenesis, the presenilins and animal models. Biochimica et Biophysica Acta. 2007; 1772(3): 285-97.

18. Ozgova S, Hermanek J, Gut I. Different antioxidant effects of polyphenols on lipid peroxidation and hydroxyl radicals in the NADPH-, Fe-ascorbate- and Fe-microsomal systems. Biochem. Pharmacol. 2003; 66: 1127-37.

19. Ozyurek M, Bektasoglu B, Guclu K, Apak R. Measurement of xanthine oxidase inhibition activity of phenolics and flavonoids with a modified cupric reducing antioxidant capacity (CUPRAC) method. Anal. Chim. Acta. 2009; 636: 42-50.

20. Padurariu M, Ciobica A, Mavroudis I, Fotiou D, Baloyannis S. Hippocampal neuronal loss in the CA1 and CA3 areas of Alzheimer's disease patients. Psychiatria Danubina. 2012; 24(2): 152-8.

21. Paxinos G, Watson C. The rat brain in stereotaxic. 4th ed. San Diago: Academic Press. (1998); p. 21.

22. Rai S, Kamat PK, Nath C, Shukla R. A study on neuroinflammation and NMDA receptor function in STZ (ICV) induced memory impaired rats. Journal of Neuroimmunology. 2013; 15: 1-9.
23. Rendeiro C, Guerreiro JD, Williams CM, Spencer JP. Flavonoids as modulators of memory and learning: molecular interactions resulting in behavioural effects. Proceedings of the Nutrition Society. 2012; 71(2): 246-62.

24. Roghani M, Baluchnejadmojarad T, Khalili M, Mahdavi Salimi SF. The effect of chronic oral administration of Withania somnifera root on learning and memory in diabetic rat using passive avoidance test. Scientific Journal of Hamadan University of Medical Sciences and Health Services. 2007; 13(2): 10-17.

25. Roghani M, Joghataie MT, Jalali MR, Baluchnejadmojarad T. Time Course of Changes in Passive Avoidance and Y-Maze performance In Male Diabetic Rats. Iranian Biomedical Journal. 2006; 10(2): 99-104.

26. Shariatifar N, Rahimnia R, Jamshidi AM, Pirali Hamedani M, Shoeibi Sh. Effect of Ethanolic Extract of Mespilus germanica on Cutaneous Leishmaniasis in BALB/c Mice. Journal of Medicinal Plants. 2011; 10(39): 76-81.

27. Spencer JP. Flavonoids and brain health: multiple effects underpinned by common mechanisms. Genes \& Nutrition. 2009; 4(4): 243-50.

28. Vareed SK, Schutzki RE, Nair MG. Lipid peroxidation, cyclooxygenase enzyme and tumor cell proliferation inhibitorycompounds in Cornus kousa fruits. Phytomedicine. 2007; 14: 706-9.

29. Vauzour D. Effect of flavonoids on learning, memory and neurocognitive performance: relevance and potential implications for Alzheimer's disease pathophysiology. Journal of the Science of Food and Agriculture. 2014; 94(6): 1042-56.

30. Verma AR, Vijayakumar M, Mathela CS, Rao CV. In vitro and in vivo antioxidant properties of different fractions of Moringa oleifera leaves. Food Chem Toxicol. 2009; 47: 2196-201.

31. Wible CG. Hippocampal Physiology, Structure and Function and the Neuroscience of Schizophrenia: A Unified Account of Declarative Memory Deficits, Working Memory Deficits and Schizophrenic Symptoms. Behavioural Sciences. 2013; 3(2): 298-315. 
Niloufar Darbandi, Matin Ramezani,

Fariba Khodagholi, Mitra Noori

KAEMPFEROLIO SKATINAMAS ATMINTIES

IŠSAUGOJIMAS IR STREPTOZOTOKINO

SUKELTAS HIPOKAMPO CA1 NEURONU

TANKIS WISTAR ŽIURKIŲ INTRA-CEREBRO-

VENTIKULINIAME EKSPERIMENTINIAME

AD MODELYJE

Santrauka

Alzheimerio liga yra progresuojanti degeneracinè liga, lemianti atminties sutrikimus, pažintinių funkcijų sumažèjimą, sugebejjimų ir elgsenos pokyčius. Kai kurie tyrimai rodo, kad flavonoidai gali prasiskverbti pro kraujo ir smegenų barjerą ir padaryti teigiamą poveikị, sumažindami neuronų pažeidimo sukeltą smegenų sutrikimą, tokị kaip Alzheimerio liga. Tyrimo metu Wistar žiurkems buvo taikomos penkios skirtingos medikamentų dozès: fiziologinis tirpalas ir fiziologinis tirpalas, streptozotokinas (3 $\mathrm{mg} / \mathrm{kg}$ ) ir fiziologinis tirpalas, streptozotokinas (3 $\mathrm{mg} / \mathrm{kg})$ ir skirtingos kaempferolio dozès $(5,7 / 5$, $10 \mathrm{mg} / \mathrm{kg}$ ). Nustatyta, kad intra-cerebroventikulinès streptozotokino injekcijos gerokai sumažina atminties išsaugojimą, bet nepažeidžia piramidinių ląstelių, palyginti su kontroline grupe. Kaempferolis priklausomai nuo dozès pagerino streptozotokino poveiki. Tyrimai rodo, kad kaempferolis gali optimizuoti pažinimo deficitą, sukeltą streptozotokino injekcijų, be to, pasižymi naudingu poveikiu hipokampo CA1 piramidiniams neuronams.

Raktažodžiai: kaempferolis, streptozotokinas, atmintis, hipokampo CA1 sritis 